Originally published as:

Schäfer, H., Burger, R.

Tools for cellular immunology and vaccine research the in the guinea pig: Monoclonal antibodies to cell surface antigens and cell lines

(2012) Vaccine, 30 (40), pp. 5804-5811.

AUTHOR MANUSCRIPT. (C) Elsevier (2012): This is the author's version of the work. It is posted here by permission of Elsevier for personal use, not for redistribution. Some changes resulting from the publishing process, such as editing, corrections, structural formatting, and other quality control mechanisms may not be reflected in this document. Some changes may have been made to this work since being accepted for publication. A definitive version was subsequently published in Vaccine, [Volume: 30, Issue: 40, 2012 Jul 20] DOI: 10.1016/j.vaccine.2012.07.012 


\title{
Tools for cellular immunology and vaccine research the in the guinea pig: Monoclonal antibodies to cell surface antigens and cell lines
}

\author{
Hubert Schäfer, Reinhard Burger \\ Robert Koch-Institute Berlin, Nordufer 20, 13353 Berlin, Germany
}

\begin{abstract}
The use of monoclonal antibodies directed against membrane proteins of leukocytes has greatly contributed to our understanding of the function and development of the immune system. Meanwhile these reagents provide valuable tools in many fields of research, stretching far beyond immunology and hematology. For guinea pigs only a limited number of such reagents have been described, and the information about availability and specificity is scattered over many years and journals. We provide an overview on the monoclonal antibodies produced since the technique was applied first in this species, with a focus on those reagents which have been characterized in more detail, and which should still be available either commercially or directly from the labs that created them.
\end{abstract}

\section{Introduction}

The term "guinea pig" is used in the English language to both refer to the animal species with the Latin name Cavia porcellus, and to indicate that a certain animal or human is used as a test subject for medical treatments or other kinds of experimental procedures. Although the species stems from the South America and has been brought to the old world first in the 16th century, it has coined our understanding of an experimental animal in a way that we use the term "experimental animal" and "guinea pig" as synonyms. Historically the guinea pig was the most widely used animal model for infections in the 18th, 19th and early 20th century, and it largely contributed to the development of the concept of infectious diseases caused by pathogenic microorganisms. Although Robert Koch had first infected mice with tubercle bacilli, he used guinea pigs to establish bacteria as the etiologic agent that causes tuberculosis [1]. The remarkable similarities between humans and guinea pigs in many physiological traits have been outlined by several authors [2] and [3], and continue to give reason to use guinea pigs as the preferred model for various diseases and pathological conditions affecting humans, even if mouse or rat models for the same subject of research exist.

Regarding the range of available strains, including mutants, transgenic breeds generated by homologous recombination, and the availability of research tools such as recombinant cytokines, assay systems, and monoclonal antibodies $(\mathrm{mAb})$ to detect and characterize cell lineages based the expression of surface antigens, the mouse is largely superior to every other experimental animal. Considering susceptibility to certain diseases, disease progression, and the immune response in infected mice however, alternative models using guinea pigs, rabbits, rats, and even non-mammalian species may turn out more suitable than mice to study a certain condition [4]. Most of these alternative models however suffer from a lack of genetically defined strains and absence of the research tools listed above. Therefore the mouse is still the most widely used animal for medical research, although for many diseases it is certainly not the best.

There is an abundance of reviews emphasizing the versatility of guinea pigs as research models in general [5], [6], [7], [8], [9], [10], [11], [12] and [13] or with reference to infectious diseases and vaccination [14], [15], [16], [17], [18], [19], [20], [21] and [22], with a strong focus on tuberculosis research [4], [23], [24], [25], [26], [27], [28], [29], [30], [31], [32], [33] and [34]. Guinea pigs represent the "gold standard" among small animal models to test the efficiency of new and established vaccines against tuberculosis [35], [36] and [37], and are useful for vaccination studies against other diseases [38], [39] and [40], but most authors agree that the limited availability of immunological reagents in this species strongly restricts its usefulness for modern experimental approaches. As a consequence 
many studies on the immune response to these diseases have been conducted in animal models that have less similarity to humans, but have more immunologic reagents available. Although many research directions could benefit from an improved availability of monoclonal antibodies in the guinea pig, the highest demand is certainly in the area of immunology, vaccination and infectious diseases.

Several obstacles have affected the development of research reagents for guinea pigs. Most of them are associated with the higher costs of purchase and care of guinea pigs as compared to mice and rats. At the same time the limited number of inbred strains and the absence of transgenic and knockout animals have made guinea pigs less attractive to researchers even if the guinea pig was the more appropriate disease model.

This review aims to summarize efforts undertaken to generate mAb directed against guinea pig differentiation antigens. Most guinea pig research reagents were generated with the intention to address a specific problem and used solely for that purpose, few studies had the concept to generally improve the availability of experimental tools for research in guinea pig models. Therefore the available information is scattered over many diverse fields of research and published in various journals that are frequently of limited importance for colleagues working in different subjects such as veterinary animal science and animal models for human placentation or arthritis. Furthermore, frequent requests to our lab for $\mathrm{mAb}$ or recombinant proteins developed by others, indicate that the demand is high but the information on the source and availability of these reagents is limited, although most of the published work is accessible via the internet.

\section{Phenotyping of leukocyte populations using differentiation antigens expressed on the cell surface}

\subsection{Cluster of differentiation antigens}

Although mAb were used to define guinea pig differentiation antigens soon after utilization of the technology in human and mouse systems, it was restricted to a few specialized labs [41], [42], [43], [44], [45] and [46] and the guinea pig field remained rather neglected when the first workshops to define clusters of differentiation (CD) in the human system were held and the nomenclature became rapidly adopted to the mouse and rat systems. Meanwhile a number of mAb to guinea pig lymphoid and myeloid differentiation antigens have been reported, but only few of them have been assigned to the CD nomenclature and even less have been confirmed by molecular biology methods.

Some of the target antigens have meanwhile been cloned and the specificity of the mAb has been confirmed by recombinant expression (see Table 1 remarks). Ideally the identity of the antigen recognized by each $\mathrm{mAb}$ should be confirmed by cloning of the coding gene and recombinant expression into host cells which are otherwise not stained by antibodies directed against the respective antigen. Alternatively identification and thorough characterization of the bound protein can be performed. Some specificities have been assigned on the basis of potential inter species crossreactivity. The anti-CD18 mAb for example were raised in mice against human CD18 and were found to cross-react with guinea pig cells. Since the target antigen in guinea pigs has not been identified by molecular methods, the specificity of the antibodies is not formally proven.

\subsection{MAb directed against cell surface antigens without cluster of differentiation classification}

Many attempts to generate $\mathrm{mAb}$ to surface antigens of guinea pig T cells were carried out in order to have a marker for the cell population under study or to analyze the consequences of antibody-binding for cellular functions. Not much attention was paid to the molecular nature of the recognized antigen or its orthologues in other species. Therefore many of these otherwise useful mAb cannot be classified following the cluster of differentiation nomenclature. These antibodies are listed in Table 2.

\subsection{MAb interfering with cellular effector functions}

Many of the mAb listed in Table 1 and Table 2 interfere with cellular effector functions by blocking binding to a physiological ligand or by mimicking interaction with this ligand. Therefore some of these antibodies are able to either block the physiological function of the target cell, whereas others show an activating effect. Antibodies directed against proteins encoded in the Major Histocompatibility Complex 
(MHC) have been shown to be important for the analysis of $\mathrm{MHC}$ restricted antigen presentation. As expected, most anti-MHC class I and anti-MHC class II antibodies interfere with the function of class I or class II restricted T lymphocytes [42], [47] and [48], i.e. inhibit the response to antigen presented on MHC molecules. Similarly, mAb to cytokine receptors inhibit the proliferation of activated T cells [44] and [49]. Binding of mAb 188 [50]and $\mathrm{H} 160$ [51] to membrane proteins of unknown function strongly inhibited antigen- and mitogen-induced T cell proliferation. Cross-linking of GPI-anchored surface proteins such as Thy 1 by mAb had a strong costimulatory effect on T cell proliferation [52].

\subsection{MAb directed against antigens of the major histocompatibility complex}

Several independent reports have described the production and utilization of anti-MHC antibodies (see Table 3 for references). Anti-class II mAb have been classified based on the expression and molecular characteristics of the recognized MHC protein, and on their capacity to interfere with class II restricted T cell responses [41] and [42]. The specificity of mAb B640 and MSgp 4 for MHC class I has been confirmed by cloning and expression of a guinea pig class I gene (unpublished). MAb potentially reactive with $\mathrm{MHC}$ antigens have been described based on immunohistological staining experiments [53], but the specificity has not been confirmed by additional methods.

\subsection{Cell surface markers for leukocyte subpopulations}

Although most of the mAb listed so far react with protein antigens on the surface of lymphocytes and macrophages, only some of them are appropriate to define populations and subpopulations within guinea leukocytes. Many membrane proteins are expressed on a variety of differentiation lineages and over long periods of cellular ontogeny. Strictly, only proteins which have a specific task at a specific state of cellular development should be expressed selectively on a group of cells with a defined function. In reverse, this means that each of these "markers" plays a role in the effector function of the cell or serves as receptor for growth factors or for signal transduction. The physiological ligands of these receptors might be a soluble mediator such as IL2 or a surface protein of an interacting cell such as MHC class I for the CD8 differentiation antigen.

\subsubsection{Pan-leukocyte markers}

Due to expression on all nucleated cells, anti-MHC class I mAb may be used to discriminate leukocytes from erythrocytes and thrombocytes in the blood and in cell suspensions from immunological organs. These antibodies however cannot be used to identify leukocytes on samples which contain other nucleated cells such as tissue sections or tumor cells. For the purpose of selectively staining leukocytes mAb H201 (anti-Leukocyte Common Antigen, CD45) can be used [54], because it provides strong staining of all leukocyte populations and low background on non-leukocytic cells. Anti-CD45 mAb specifically recognizing individual isoforms of the leukocyte common antigen have been described, which might turn out helpful for the discrimination between native and memory $T$ cells subsets (Table 1$)$.

\subsubsection{Lymphocyte markers}

In analogy to the rat system and in contrast to mice, Thy-1 (CD90) is expressed on T-and B-cells in guinea pigs, although staining of T-lymphocytes using $\mathrm{mAb} \mathrm{H} 154$ is somewhat stronger than that of $\mathrm{B}$ cells, and germinal center B cells are completely negative [52]. Therefore antibodies against Thy- 1 are not $T$ cell markers in this species. Moreover fibroblasts, Langerhans cells and activated macrophages stain positive for Thy-1, very weak staining is observed on guinea pig erythrocytes. As in most other species, guinea pig Thy- 1 is strongly expressed in the brain. In whole blood samples and single cells suspensions of spleen and lymph nodes anti-Thy-1 mAb might be useful to discriminate strong staining lymphocytes (B- and T cells) from weak or non-stained macrophages and granulocytes. Both in tissue sections and in single cell suspensions anti-Thy- $1 \mathrm{mAb}$ are helpful to dissect fibroblasts from epithelial or endothelial cells [52]. Based on the expression of Thy-1 we consider the guinea pig cell line $104 \mathrm{C} 1$ [55] as a fibroblast line whereas $\mathrm{JH} 4$ clone 1, which has a similar morphology is rather of epithelial or endothelial origin (Thy-1 negative). The L2C B cell leukemia line is negative for Thy-1, thus resembling germinal center B cells of the lymph node (Table 4). 


\subsection{3. $T$ cells}

Only very few mAb can be used as pan T-cell markers in the guinea pig, when compared to human or mouse cells. As outlined above Thy- 1 is not restricted to T cells in the guinea pig and the expression of CD2 which is sometimes used as a T cell marker on human cells has not been identified in guinea

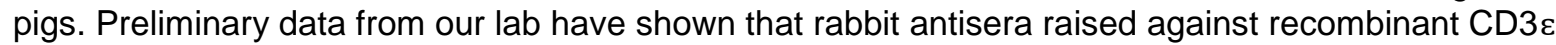
can be used to selectively stain T cells, but so far we have not been able to obtain a monoclonal antiCD3 from immunized mice. MAb PC3/188 was raised against a conserved peptide of the CD3 $\varepsilon$ chain [56], which is also present on guinea pig T cells, but due to the cytoplasmic location of the epitope, the antibody only works with intracellular staining after permeabilization of the cell membrane. Therefore the best marker for T-lymphocyte in our hands has been mAb H159 [57]. Although there is weak staining of $\mathrm{B}$ cells, both populations can be fully separated using $\mathrm{H} 159$ both on tissue sections and by flow cytometry, the recognized antigen however has not been elucidated, although molecular data on the protein have been obtained. Based on these data we proposed $\mathrm{H} 159$ to be specific for the $\mathrm{T}$ cell receptor, but subsequent analysis of TCR proteins and comparison to the antigen detected by $\mathrm{H} 159$ argue against this hypothesis. Activated T lymphocytes and, to a minor extend, resting $\mathrm{T}$ cells and thymocytes, express la antigens in the guinea pig [58].

\subsubsection{T cell subpopulations}

The CD4- and CD8-positive subpopulations can be identified with several independently obtained mAb. The CD4-antigen is recognized by mAb H155 [59] and CT7, although the latter has initially been described as a pan-T cell marker [60] and cross-blocking studies with $\mathrm{H} 155$ have not been carried out so far.

The antibodies B607, CT6, and MSgp6 [47] and [60] all react with the alfa-chain of guinea pig CD8, which has meanwhile been confirmed by cloning of guinea pig CD8-alfa and transfection into mouse cells (unpublished). CT6 and B607 are of the same isotype (mouse $\lg \mathrm{G} 1$ ) and stain quite strongly, whereas MSgp6 [61] is a mouse lgM antibody and shows weaker staining.

Examples for the use of anti-CD4 and anti-CD8 antibodies have been shown exemplarily [47]. In double staining experiments individual subpopulations of CD4 and CD8 single positive or double positive cells can be distinguished. The same mAb can be used to differentiate responding cells after CFSE-labeling and proliferation. Most of these antibodies have been used successfully to identify the recognized T cell subsets in cryosections [59], [60] and [61].

\subsubsection{B cells}

Surface IgM bearing B-lymphocytes can be reliably discriminated from other leukocyte populations by $\mathrm{mAb} 31 \mathrm{D} 2$ and B621, both directed against guinea pig $\operatorname{lgM}$. After mice and rats were immunized with lymph node cells, B cell specific $\mathrm{mAb}$ were identified by immunohistochemistry and flow cytometry. Further analysis of the recognized antigen showed that 31D2 reacts both with soluble IgM and with surface IgM on B lymphocytes. This antibody may be used to deplete B cells from lymph node cells in vitro [62]. The specificity of B621 was deduced by partial cross-blocking with 31D2 and by the fact that pre-incubation with whole blood (containing soluble $\operatorname{lgM}$ ) abolishes reactivity with lymphocytes. Most $B$ cells as well as the ENL2C leukemia line are also stained by anti-MHC class II mAb 22C4 and MSgp8 [61].

\subsubsection{Macrophages}

Macrophages are represented by a variety of different cells types in many different organs. Most of these differentiation lineages have their own morphology and may possess quite different sets of surface antigens. In general most macrophages will express MHC class I antigens (strong staining) and class II antigens (variable), the leukocyte common antigen (strong), Thy1 (variable depending on activation state) and the antigen recognized by mAb H160 (unpublished). These surface antigens are shared with many other cells and can therefore not be considered as macrophage markers. Several authors have reported the generation of $\mathrm{mAb}$ specific for guinea pig macrophages with a broader or narrower expression profile on different macrophage lineages. MAb 342 [63] and MR-1 [64] provide specific and sensitive staining of a broad range of macrophages. Due to the intracellular expression of 
the recognized antigen, MR-1 is better suited for immunohistochemistry experiments, whereas mAb 342 can be used for flowcytometry as well.

\subsection{Cross-reactive mAb}

A number of reports have been published on cross-reactive mAb which have been submitted to cluster of differentiation workshops for human cells and were simultaneously tested for reactivity with other species [65], [66] and [67]. Although this is potentially a fast and straightforward way to obtain useful $\mathrm{mAb}$ directed against guinea pig differentiation antigens, it has to be kept in mind that a positive reaction of a certain antibody with a guinea pig cell population does by no means guarantee that the homologous antigen is actually detected. A detailed characterization of the recognized antigen is urgently recommended. In the latest report $15 \mathrm{mAb}$ out of 367 raised against human $C D$ antigens showed clear cross-reactivity. Five of those however showed staining patterns in guinea pigs which were inconsistent with those reported in humans, and for some other antibodies no appropriate guinea pig target cells were available for further testing. For eight CD specificities it was concluded that, based on the staining pattern, the respective orthologue in the guinea pig was detected, a detailed analysis of the recognize antigen however has not been published so far. In a more successful approach three out of three mAb directed against human la antigens were found to react with la epitopes of strain 2 guinea pig cells [45]. Similarly, by checking available human anti-CD1 mAb several clones were found to cross-react with guinea pig CD1 antigens [68]. Rational design of the immunizing peptide based on sequence homology of $C D$-antigens between different species yielded $\mathrm{mAb}$ reacting with the target antigen of several animal species including guinea pigs [56].

\section{Cell-lines and $T$ cell hybrids}

In the guinea pig system only a few cell lines showing autonomous growth in tissue culture or as transplantable tumors are available. Tissue culture for a variety of primary cells usually can be carried out following the protocols developed in other species.

\subsection{Guinea pig tumor cell lines}

Unfortunately no lymphocytic or myeloid cell line that can be grown in culture has been obtained from guinea pigs so far, restricting the options to immunize and screen with a highly homologous cell population for the generation of mAb. The available cell lines were mostly induced by treatment with chemical carcinogens and show a rather limited expression of cell surface antigens that can be detected with the available mAb. The fibroblast line 104C1 expresses MHC class I and Thy-1 antigens. The $B$ cell leukemia $\mathrm{ENL}_{2} \mathrm{C}$ is positive for surface $\mathrm{lgM}$, and class I and class II MHC. The variant $B Z L_{2} C$ is an la negative subclone of the parental $L_{2} C$ cells [69].

\section{2. $T$ cell lines and clones}

Alloreactive and antigen-specific $T$ cell lines can be obtained be repeated restimulation of primed $T$ lymphocytes in the presence of guinea pig IL2 or IL15. Expansion and cloning of these cells is achieved by following standard protocols [70], [71], [72] and [47]. Cells grown by repeated restimulation maintain cellular effector functions in vitro. To obtain highly pure populations of $T$ cells in vitro, stimulated T lymphocytes can be grown in medium containing IL2 or IL15 without adding macrophages for antigen presentation. Some of these cultures have been grown for several months in our laboratory and continue to express T cell markers such as CD3 and the coreceptors CD4 or CD8 (unpublished observation).

\section{3. $\mathrm{T}$ cell hybrids}

We have shown, that guinea pig T cells can be fused with mouse and rat thymoma cell lines to produce $T$ cell hybrids stably expressing guinea pig cell surface antigens [73]. Although these hybrids might be helpful to further characterize the binding specificity of $\mathrm{mAb}$, they appear useless for functional studies, because none of these hybrids responded to polyclonal stimulation with the release of interleukin 2 (unpublished). 


\section{Outlook}

Although the use of guinea pigs as experimental models apparently declines, there is still an increasing demand for research reagents in this species. The reasons for the lack of such tools have been discussed above, and the drawbacks of the guinea pig system in general, such as high cost, long gestation period, few inbred strains and no transgenic animals, are not likely to be resolved in the near future, which will in turn prevent many researchers form establishing guinea pig models in their lab. Therefore the community of "guinea pig researchers" will remain rather small compared to research groups employing mouse models. As a consequence it is rather unlikely that commercial suppliers will broaden their range of products in this category, so most of new reagents will have to be developed in scientific labs. Raising monoclonal and polyclonal antibodies to guinea pig proteins has become much easier with the sequencing of the guinea pig genome. We have used the information from public genome libraries to confirm the specificity of mAb against class I molecules and for recombinant expression of guinea pig cytokines and differentiation antigens (manuscript in preparation). These recombinant proteins have been used successfully to generate monoclonal and polyclonal antibodies, which represents a considerable improvement over the use of crude antigens such as whole cells or cellular supernatants as immunizing agents. Since guinea pigs, mice and rats are quite closely related on the phylogenetic tree, it is sometimes not possible to generate antibodies to certain guinea pig proteins in mice or rats. This obstacle has been overcome in the mouse system by using hamsters as hosts for the induction of an immune response [74]. We have found, that rabbits respond much better to certain recombinant guinea pig antigens than mice or rats (manuscript in preparation), and that rabbit polyclonal antibodies raised against guinea pig $T$ cell differentiation antigens expressed in Escherichia coli can be used to specifically detect the protein on the cell surface by flow cytometry. With the recently described parental cell line developed in transgenic rabbits [75] it should be possible to produce mAb with the same specificity. The technique however is currently limited to commercial suppliers, because the parental line has not been made available to research laboratories.

Conflicts of interest statement: The authors have no conflicts of interest to declare 


\section{References}

[1] Koch R. Die Aetiologie der Tuberkulose. Berliner Klinische Wochenschrift 1882;19(15).

[2] Gupta UD, Katoch VM. Animal models of tuberculosis. Tuberculosis (Edinb) 2005;85(SeptemberNovember (5-6)):277-93.

[3] McMurray DN. Guinea pig model of tuberculosis. In: Bloom BR, editor. Tuberculosis-

pathogenesis, protection, and control. Washington, DC: ASM Press; 1994. p. 135-48.

[4] Gupta UD, Katoch VM. Animal models of tuberculosis for vaccine development. Indian J Med Res 2009;129(January (1)):11-8.

[5] Canning BJ, Chou Y. Using guinea pigs in studies relevant to asthma and COPD. Pulm Pharmacol Ther 2008;21(October (5)):702-20.

[6] Carter AM. Animal models of human placentation - a review. Placenta 2007;28(April (Suppl.

A)):S41-7.

[7] Dinser R. Animal models for arthritis. Best Pract Res Clin Rheumatol 2008;22(April (2)):253-67.

[8] Maurer T. Guinea pigs in hypersensitivity testing. Methods 2007;41(January (1)):48-53.

[9] Nauta A, Knippels L, Garssen J, Redegeld F. Animal models of anaphylaxis. Curr Opin Allergy Clin Immunol 2007;7(August (4)):355-9.

[10] Ricciardolo FL, Nijkamp F, De Rose V, Folkerts G. The guinea pig as an animal model for asthma. Curr Drug Targets 2008;9(June (6)):452-65.

[11] Wagner JG, Harkema JR. Rodent models of allergic rhinitis: relevance to human pathophysiology. Curr Allergy Asthma Rep 2007;7(May (2)):134-40.

[12] Xiangdong L, Yuanwu L, Hua Z, Liming R, Qiuyan L, Ning L. Animal models for the atherosclerosis research: a review. Protein Cell 2011;2(March (3)): 189-201.

[13] Zosky GR, Sly PD. Animal models of asthma. Clin Exp Allergy 2007;37(July (7)):973-88.

[14] Carroll SF, Guillot L, Qureshi ST. Mammalian model hosts of cryptococcal infection. Comp Med 2007;57(February (1)):9-17.

[15] Clemons KV, Capilla J, Stevens DA. Experimental animal models of coccidioidomycosis. Ann N Y Acad Sci 2007;September (1111):208-24.

[16] Gowen BB, Holbrook MR. Animal models of highly pathogenic RNA viral infections: hemorrhagic fever viruses. Antiviral Res 2008;78(April (1)):79-90.

[17] Hickey AJ. Guinea pig model of infectious disease - viral infections. Curr Drug Targets 2011;12(June (7)):1018-23.

[18] Padilla-Carlin DJ, McMurray DN, Hickey AJ. The guinea pig as a model of infectious diseases. Comp Med 2008;58(August (4)):324-40.

[19] Silva TM, Costa EA, Paixao TA, Tsolis RM, Santos RL. Laboratory animal models for brucellosis research. J Biomed Biotechnol 2011;2011:518323.

[20] Vanrompay D, Lyons JM, Morre SA. Animal models for the study of Chlamydia trachomatis infections in the female genital infection. Drugs Today (Barc) 2006;42(March (Suppl. A)):55-63. [21] Weingartl HM, Berhane Y, Czub M. Animal models of henipavirus infection: a review. Vet J 2009;181(September (3)):211-20.

[22] Rank RG, Whittum-Hudson JA. Protective immunity to chlamydial genital infection: evidence from animal studies. J Infect Dis 2010;201(June (Suppl. 2)):S168-77.

[23] Basaraba RJ. Experimental tuberculosis: the role of comparative pathology in the discovery of improved tuberculosis treatment strategies. Tuberculosis (Edinb) 2008;88(August (Suppl. 1)):S35-47. [24] Dharmadhikari AS, Nardell EA. What animal models teach humans about tuberculosis. Am J Respir Cell Mol Biol 2008;39(November (5)):503-8.

[25] Gupta UD, Katoch VM, McMurray DN. Current status of TB vaccines. Vaccine 2007;25(May (19)):3742-51.

[26] Helke KL, Mankowski JL, Manabe YC. Animal models of cavitation in pulmonary tuberculosis. Tuberculosis (Edinb) 2006;86(September (5)):337-48.

[27] Nuermberger E. Using animal models to develop new treatments for tuberculosis. Semin Respir Crit Care Med 2008;29(October (5)):542-51.

[28] O'Toole R. Experimental models used to study human tuberculosis. Adv Appl Microbiol 2010;71:75-89.

[29] Okada M, Kita Y. Tuberculosis vaccine development: the development of novel (preclinical) DNA vaccine. Hum Vaccin 2010;6(April (4)):297-308.

[30] Orme IM. The use of animal models to guide rational vaccine design. Microbes Infect 2005;7(May (5-6)):905-10.

[31] Orme IM. Current progress in tuberculosis vaccine development. Vaccine 2005;23(March (17-

18)):2105-8.

[32] Orme IM. Preclinical testing of new vaccines for tuberculosis: a comprehensive review. Vaccine 2006;24(January (1)):2-19.

[33] Parida SK, Kaufmann SH. Novel tuberculosis vaccines on the horizon. Curr Opin Immunol 2010;22(June (3)):374-84. 
[34] Reed S, Lobet $Y$. Tuberculosis vaccine development; from mouse to man. Microbes Infect 2005;7(May (5-6)):922-31.

[35] Horwitz MA, Harth G, Dillon BJ, Maslesa-Galic S. Commonly administered BCG strains including an evolutionarily early strain and evolutionarily late strains of disparate genealogy induce comparable protective immunity against tuberculosis. Vaccine 2009;27(January (3)):441-5.

[36] Williams A, Hatch GJ, Clark SO, Gooch KE, Hatch KA, Hall GA, et al. Evaluation of vaccines in the EU TB Vaccine Cluster using a guinea pig aerosol infection model of tuberculosis. Tuberculosis (Edinb) 2005;85(January-March (1-2)):29-38.

[37] Williams A, Hall Y, Orme IM. Evaluation of new vaccines for tuberculosis in the guinea pig model. Tuberculosis (Edinb) 2009;89(November (6)):389-97.

[38] Schleiss MR. Comparison of vaccine strategies against congenital CMV infection in the guinea pig model. J Clin Virol 2008;41(March (3)):224-30.

[39] McLaren DJ, Delgado VS, Gordon JR, Rogers MV. Schistosoma mansoni: analysis of the humoral and cellular basis of resistance in guinea-pigs vaccinated with radiation-attenuated cercariae.

Parasitology 1990;100(February (Pt 1)): 35-44.

[40] Bartels T, Schafer H, Liebermann H, Burger R, Beyer J. T-lymphocyte responses in guinea pigs vaccinated with foot-and-mouth disease virus. Vet Immunol Immunopathol 1994;40(March (3)):21323.

[41] Burger R, Clement L, Schroer J, Chiba J, Shevach EM. Monoclonal antibodies to guinea pig la antigens. I. Production, serologic, and immunochemical characterization. J Immunol 1981;126(January (1)):32-7.

[42] Burger R, Shevach EM. Monoclonal antibodies to guinea pig la antigens. II. Effect on alloantigen-, antigen-, and mitogen-induced T lymphocyte proliferation in vitro. J Exp Med 1980;152(October

(4)):1011-23.

[43] Chiba J, Chused TM, Leiserson WM, Zweig SE, Shevach EM. Production and characterization of monoclonal antibodies to guinea pig lymphoid differentiation antigens. J Immunol Methods 1983;63(October (2)):247-61.

[44] Malek TR, Robb RJ, Shevach EM. Identification of a membrane antigen that is distinct from the interleukin 2 receptor and that may be required for interleukin 2-driven proliferative responses. $\mathrm{J}$ Immunol 1983;130(February (2)):747-55.

[45] Zweig SE, Ferrone S, Shevach EM. Monoclonal antibodies directed against human la antigens detect an evolutionary conserved epitope on guinea pig la antigens with unique functional properties. J Leukoc Biol 1984;35(January (1)):101-13.

[46] Zweig SE, Shevach EM. Production and properties of monoclonal antibodies to guinea pig la antigens. Methods Enzymol 1983;92:66-85.

[47] Schafer H, Scheper RJ, Borsdorf B, Burger R. Effector functions of CD8-positive guinea pig T lymphocytes. Cell Immunol 2003;222(April (2)):134-43.

[48] Healey DG, Agha N, Turk JL. Behaviour of guinea pig T cells stimulated by antigen, allo-antigen and mitogen. Int Arch Allergy Appl Immunol 1988;87(2):134-42.

[49] Malek TR, Shevach EM. Interleukin 2-driven T lymphocyte proliferation is dependent upon a surface antigen distinct from the interleukin 2 receptor: requirements for inhibition of T-cell proliferation by monoclonal antibody 5C3. Cell Immunol 1984;84(March (1)):85-93.

[50] Schrod L, Schaefer H, Burger R. Characterization of a T-lymphocyte membrane protein involved in T-cell function: its contribution to T-cell recognition or cellular interaction. Immunology 1986;57(April (4)):533-8.

[51] Burger R, Schrod L, Schaefer $H$. Functionally relevant membrane proteins of human and guineapig T lymphocytes. Mol Immunol 1986;23(November (11)):1149-56.

[52] Schafer H, Bartels T, Hahn G, Otto A, Burger R. T-cell-activating monoclonal antibodies, reacting with both leukocytes and erythrocytes, recognize the guinea pig Thy-1 differentiation antigen:

characterization and cloning of guinea pig CD90. Cell Immunol 1999;197(November (2)):116-28.

[53] Sato H, Inaba T, Kamiya H. Production of murine monoclonal antibodies to guinea pig leukocytes and immunohistochemistry of guinea pig skin exposed to Schistosoma mansoni. Hybridoma 1997;16(December (6)):529-36.

[54] Schafer H, Baker D, Thiele B, Burger R. Structure, cellular distribution, and functional characteristics of the guinea pig leucocyte common antigen. Cell Immunol 1990;128(July (2)):370-84. [55] Evans $\mathrm{CH}$, DiPaolo JA. Neoplastic transformation of guinea pig fetal cells in culture induced by chemical carcinogens. Cancer Res 1975;35(April (4)):1035-44.

[56] Jones M, Cordell JL, Beyers AD, Tse AG, Mason DY. Detection of $T$ and B cells in many animal species using cross-reactive anti-peptide antibodies. J Immunol 1993;150(June (12)):5429-35.

[57] Schafer H, Burger R. Analysis of mature guinea pig T cells with a monoclonal antibody directed against a framework determinant of the T-cell receptor for antigen. Scand J Immunol 1992;36(October (4)):587-95. 
[58] Burger R, Scher I, Sharrow SO, Shevach EM. Non-activated guinea-pig T cells and thymocytes express la antigens: FACS analysis with alloantibodies and monoclonal antibodies. Immunology 1984;51(January (1)):93-102.

[59] Schafer H, Burger R. Identification and functional characterization of guineapig CD4: antibody binding transduces a negative signal on T-cell activation. Immunology 1991;72(February (2)):261-8. [60] Tan BT, Ekelaar F, Luirink J, Rimmelzwaan G, De Jonge AJ, Scheper RJ. Production of monoclonal antibodies defining guinea pig T-cell surface markers and a strain 13 la-like antigen: the value of immunohistological screening. Hybridoma 1985;4(Summer (2)):115-24.

[61] Baker D, Healey DG, Verghese S, Schafer H, Turk JL. Phenotypic analysis of guinea pig Langerhans cells with antibodies directed against leucocyte surface antigens. Int Arch Allergy Appl Immunol 1988;86(3):350-5.

[62] Jarjour WN, Asofsky R, Raine CS, Stone SH. Transfer of autoimmune encephalomyelitis with T lymphocytes in strain 13 guinea pigs. Cell Immunol 1986;103(December (2)):462-8.

[63] Mauer-Gross U, von Steldern D, Hadding U, Bitter-Suermann D, Burger R. Cell surface antigens on the guinea-pig macrophage: identification by monoclonal antibodies and association with the activation state. Immunology 1985;55(July (3)):519-30.

[64] Kraal G, Shiamatey-Koolma R, Hoffer M, Baker D, Scheper R. Histochemical identification of guinea-pig macrophages by monoclonal antibody MR-1. Immunology 1988;65(December (4)):523-8. [65] Brodersen R, Bijlsma F, Gori K, Jensen KT, Chen W, Dominguez J, et al. Analysis of the immunological cross reactivities of 213 well characterized monoclonal antibodies with specificities against various leucocyte surface antigens of human and 11 animal species. Vet Immunol Immunopathol 1998;64(June (1)):1-13.

[66] Lasco TM, Gonzalez-Juarrero M, Saalmuller A, Lunney JK. Cross-reaction of antihuman CD monoclonal antibodies on guinea pig cells: a summary of the guinea pig section of the HLDA8 animal homologues data. Vet Immunol Immunopathol 2007;119(September (1-2)):131-6.

[67] Saalmuller A, Aasted B. Summary of the animal homologue section of HLDA8. Vet Immunol Immunopathol 2007;119(September (1-2)):2-13.

[68] Hiromatsu K, Dascher CC, Sugita M, Gingrich-Baker C, Behar SM, LeClair KP, et al. Characterization of guinea-pig group 1 CD1 proteins. Immunology 2002;106(June (2)):159-72. [69] Forni G, Shevach EM, Green I. Mutant lines of guinea pig L2C leukemia. I. Deletion of la alloantigens is associated with a loss in immunogenicity of tumor-associated transplantation antigens. Exp Med 1976;143(May (5)): 1067-81.

[70] Clark RB, Shevach EM. Generation of T cell colonies from responder strain 2 guinea pigs that recognize the copolymer I-glutamic acid, I-lysine in association with nonresponder strain 13 la antigens. J Exp Med 1982;155(February (2)):635-40.

[71] DosReis GA, Shevach EM. Analysis of autoreactive I region-restricted T cell colonies isolated from the guinea pig syngeneic mixed leukocyte reaction and from immune responses to conventional foreign antigens. Eur J Immunol 1985;15(May (5)):466-72.

[72] Malek TR, Clark RB, Alloreactive Shevach EM. T cells from individual soft agar colonies specific for guinea pig la antigens. I. Production and initial characterization. J Immunol 1981;127(August

(2)):616-21.

[73] Schafer H, Muller B, Bader A, Schenkel J, Burger R. Analysis of guinea pig leukocyte antigens using interspecies T cell hybrids. J Immunol Methods 1989;118(March (2)):169-77.

[74] Leo O, Foo M, Sachs DH, Samelson LE, Bluestone JA. Identification of a monoclonal antibody specific for a murine T3 polypeptide. Proc Natl Acad Sci U S A 1987;84(March (5)):1374-8.

[75] Spieker-Polet H, Sethupathi P, Yam PC, Knight KL. Rabbit monoclonal antibodies: generating a fusion partner to produce rabbit-rabbit hybridomas. Proc Natl Acad Sci U S A 1995;92(September (20):9348-52.

[76] Behar SM, Porcelli SA, Beckman EM, Brenner MB. A pathway of costimulation that prevents anergy in CD28-T cells: B7-independent costimulation of CD1-restricted T cells. J Exp Med 1995;182(December (6)):2007-18.

[77] Sobel RA, Blanchette BW, Russo MA, Williams AM, Colvin RB. Anti-T cell monoclonal antibodies in vivo. II. Modulation of acute and chronic experimental allergic encephalomyelitis (EAE) in guinea pigs. J Immunol 1987;138(April (8)):2507-13.

[78] Sobel RA, Hanzakos JL, Blanchette BW, Williams AM, Dellapelle P, Colvin RB. Anti-T cell monoclonal antibodies in vivo. I. Inhibition of delayed hypersensitivity but not cutaneous basophil hypersensitivity reactions. J Immunol 1987;138(April (8)):2500-6.

[79] Dilwith R, Wicher K. C.D5+ and CD5-B1-like lymphocytes in healthy guinea pig. Clin Immunol Immunopathol 1997;85(November (2)):143-50.

[80] Nagarajan UM, O'Connell C, Rank RG. Molecular characterization of guinea-pig (Cavia porcellus) CD8alpha and CD8beta cDNA. Tissue Antigens 2004;63(February (2)):184-9.

[81] Kaslovsky RA, Horgan MJ, Lum H, McCandless BK, Gilboa N, Wright SD, et al. Pulmonary edema induced by phagocytosing neutrophils. Protective effect of monoclonal antibody against phagocyte CD18 integrin. Circ Res 1990;67(October (4)):795-802. 
[82] Noonan TC, Gundel RH, Desai SN, Stearns C, Barton RW, Rothlein R, et al. The effects of an anti-CD18 antibody (R15.7) in antigen-induced airway hyperresponsiveness (AH) and cell influx in guinea pigs. Agents Actions 1991;34(September (1-2)):211-3.

[83] Hart IJ, Schafer H, Scheper RJ, Stevenson GT. Subpopulations of guinea-pig T lymphocytes defined by isoforms of the leucocyte common antigen. Immunology 1992;77(November (3)):377-84. [84] Nishikawa K, Matsuo S, Tamai H, Okada N, Okada H. Tissue distribution of the guinea-pig decayaccelerating factor. Immunology 1998;95(October (2)):302-7.

[85] Okada N, Tanaka H, Takizawa H, Okada H. A monoclonal antibody that blocks the complement regulatory activity of guinea pig erythrocytes and characterization of the antigen involved as guinea pig decay-accelerating factor. J Immunol 1995;154(June (11)):6103-11.

[86] Horikawa T, Komohara Y, Kiyota E, Terasaki Y, Takagi K, Takeya M. Detection of guinea pig macrophages by a new CD68 monoclonal antibody, PM-1K. J Mol Histol 2006;37(January 1-2):15-25. [87] Kraal G, Twisk A, Tan B, Scheper R. A surface molecule on guinea pig lymphocytes involved in adhesion and homing. Eur J Immunol 1986;16(December (12)):1515-9.

[88] Healey DG, Baker D, Gschmeissner SE, Turk JL. An antigenic determinant common to lymphocytes and Langerhans cells of the guinea pig. Int Arch Allergy Appl Immunol 1987;82(2):120-4.

[89] Shimamura T, Nakamura T, Koyama J. Demonstration of the existence of two distinct Fc receptors for IgG isotypes on guinea-pig macrophages by the use of monoclonal antibodies. Mol Immunol 1987;24(January (1)):67-74.

[90] Hoying J. Selection and histochemical identification of epithelial-like cells from guinea pig lung; 1975.

[91] O'Donnell RW, Cockerell GL. Establishment and biological properties of a guinea pig colonic adenocarcinoma cell line induced by N-methyl-N-nitrosourea. Cancer Res 1981;41(June (6)):2372-7. [92] Shevach EM, Ellman L, Davie JM, Green I. L2C Guinea pig lymphatic leukemia: a B cell leukemia. Blood 1972;39(January (1)):1-12.

[93] Green I, Forni G, Konen T, Hu CP, Schwartz BD, Kask A, et al. Immunological studies of the guinea pig L2C leukemia. Fed Proc 1977;36(August (9)):2264-7.

[94] Konen TG, Green I, Shevach EM, Kask AM, Schwartz BD. Mutant lines of guinea pig L2C leukemia. III. The reaction of an alloantiserum detecting idiotypic determinants on a clonally derived guinea pig B cell leukemia with IgM and la molecules. J Immunol 1976;117(November (5 Pt 2)):196670.

[95] Rapp HJ, Churchill Jr WH, Kronman BS, Rolley RT, Hammond WG, Borsos T. Antigenicity of a new diethylnitrosamine-induced transplantable guinea pig hepatoma: pathology and formation of ascites variant. J Natl Cancer Inst 1968;41(July (1)):1-7. 


\section{Tables}

Table 1. Monoclonal antibodies against cluster of differentiation antigens of the guinea pig.

\begin{tabular}{|c|c|c|c|c|}
\hline $\begin{array}{c}\text { Cluster of } \\
\text { differentiation }\end{array}$ & $\begin{array}{l}\text { Recognized guinea } \\
\text { pig antigen }\end{array}$ & $\begin{array}{l}\text { Antibody } \\
\text { name } \\
\text { Species } \\
\text { Isotype }\end{array}$ & Remarks & Ref. \\
\hline CD1 & CD1b3 & $\begin{array}{l}\text { MSgp9 } \\
\text { Mouse } \\
\text { lgG1 }\end{array}$ & $\begin{array}{l}\text { Expressed on B cells } \\
\text { and thymocytes, gene } \\
\text { cloned }\end{array}$ & [68] \\
\hline CD1 & CD1 & $\begin{array}{l}\text { BCD1b3.1 } \\
\text { Mouse IgG1 }\end{array}$ & $\begin{array}{l}\text { Raised against human } \\
\text { CD1 } \\
\text { Cross-reactive to } \\
\text { guinea pig }\end{array}$ & [76] \\
\hline CD1 & Most CD1 isoforms & $\begin{array}{l}\text { CD1F2/5E3 } \\
\text { Mouse IgG1 }\end{array}$ & $\begin{array}{l}\text { Specificity verified on } \\
\text { transfected cell lines }\end{array}$ & [68] \\
\hline CD1 & All CD1 isoforms & $\begin{array}{l}\text { CD1F2/6B5 } \\
\text { Mouse IgG1 }\end{array}$ & $\begin{array}{l}\text { Specificity verified on } \\
\text { transfected cell lines }\end{array}$ & [68] \\
\hline CD1 & $\begin{array}{l}\text { CD1b2, CD1b3, } \\
\text { CD1b4 }\end{array}$ & $\begin{array}{l}\text { CD1F2/1B12 } \\
\text { Mouse IgG2a }\end{array}$ & $\begin{array}{l}\text { Specificity verified on } \\
\text { transfected cell lines }\end{array}$ & [68] \\
\hline CD1 & CD1b1 & $\begin{array}{l}\text { CD1.4-1D12 } \\
\text { Mouse IgG }\end{array}$ & $\begin{array}{l}\text { Specificity verified on } \\
\text { transfected cell lines }\end{array}$ & [68] \\
\hline CD3 & CD3 epsilon-chain & $\begin{array}{l}\text { PC3/188A } \\
\text { Mouse }\end{array}$ & $\begin{array}{l}\text { Intracellular staining } \\
\text { only }\end{array}$ & [56] \\
\hline CD4 & CD4 coreceptor & $\begin{array}{l}\text { H155 } \\
\text { Rat } \\
\text { IgG2a }\end{array}$ & $\begin{array}{l}\text { Inhibits T cell- } \\
\text { proliferation }\end{array}$ & [59] \\
\hline CD4 & CD4 coreceptor & $\begin{array}{l}\text { CT7 } \\
\text { Mouse } \\
\text { lgG1 }\end{array}$ & & [60] \\
\hline CD5 & CD5 & 8BE6 & & $\begin{array}{l}\text { [77], } \\
\text { [78] and [79] }\end{array}$ \\
\hline CD8 & CD8 alfa-chain & $\begin{array}{l}\text { B607 } \\
\text { Mouse } \\
\text { lgG1 }\end{array}$ & $\begin{array}{l}\text { Binds to CD8a chain, } \\
\text { gene cloned, specificity } \\
\text { verified on transfected } \\
\text { cell lines }\end{array}$ & [47] \\
\hline CD8 & CD8 alfa-chain & $\begin{array}{l}\text { CT6 } \\
\text { Mouse } \\
\text { lgG1 }\end{array}$ & $\begin{array}{l}\text { Binds to CD8a chain, } \\
\text { gene cloned, specificity } \\
\text { verified on transfected } \\
\text { cell lines }\end{array}$ & [60] \\
\hline CD8 & CD8 alfa-chain & $\begin{array}{l}\text { MSgp6 } \\
\text { Mouse } \\
\text { lgM }\end{array}$ & $\begin{array}{l}\text { Binds to CD8a chain, } \\
\text { gene cloned [80], } \\
\text { specificity verified on } \\
\text { transfected cell lines }\end{array}$ & [47] and [61] \\
\hline CD18 & $\begin{array}{l}\text { Beta-chain of } \\
\text { leukocyte adhesion } \\
\text { receptors (integrins) } \\
\text { LFA-1, Mac- } 1 \text {, etc. }\end{array}$ & $\begin{array}{l}\text { IB4 } \\
\text { Mouse }\end{array}$ & $\begin{array}{l}\text { Raised against human } \\
\text { CD18, cross-reactive to } \\
\text { guinea pig }\end{array}$ & [81] \\
\hline CD18 & $\begin{array}{l}\text { Beta-chain of } \\
\text { leukocyte adhesion } \\
\text { receptors (integrins) } \\
\text { LFA-1, Mac- } 1 \text {, etc. }\end{array}$ & $\begin{array}{l}\text { R15.7 } \\
\text { Mouse }\end{array}$ & $\begin{array}{l}\text { Raised against human } \\
\text { CD18, cross-reactive to } \\
\text { guinea pig }\end{array}$ & [82] \\
\hline CD45 & $\begin{array}{l}\text { Leukocyte common } \\
\text { antigen (LCA) all } \\
\text { isoforms }\end{array}$ & $\begin{array}{l}\mathrm{H} 201 \\
\text { Rat } \\
\text { IgG2a }\end{array}$ & $\begin{array}{l}\text { Binds all isoforms of } \\
\text { gpLCA }\end{array}$ & [54] \\
\hline CD45 & $\begin{array}{l}\text { Leukocyte common } \\
\text { antigen (LCA) all }\end{array}$ & $\begin{array}{l}\mathrm{IH}-1 \\
\text { Mouse }\end{array}$ & Similar to $\mathrm{H} 201$ & [83] \\
\hline
\end{tabular}




\begin{tabular}{|c|c|c|c|c|}
\hline $\begin{array}{c}\text { Cluster of } \\
\text { differentiation }\end{array}$ & $\begin{array}{l}\text { Recognized guinea } \\
\text { pig antigen }\end{array}$ & $\begin{array}{l}\text { Antibody } \\
\text { name } \\
\text { Species } \\
\text { Isotype }\end{array}$ & Remarks & Ref. \\
\hline & isoforms & $\lg \mathrm{G} 1$ & & \\
\hline CD45 & LCA isoform-specific & $\begin{array}{l}\mathrm{IH}-2 \\
\text { Mouse } \\
\text { IgG1 }\end{array}$ & $\begin{array}{l}\text { Reacts with most } \\
\text { leucocytes and } \\
\text { thymocytes }\end{array}$ & [83] \\
\hline CD45 & LCA isoform-specific & $\begin{array}{l}\mathrm{IH}-4 \\
\text { Mouse } \\
\text { lgG1 }\end{array}$ & $\begin{array}{l}\text { Reacts with most } \\
\text { leucocytes, but only } \\
\text { with a minor portion of } \\
\text { thymocytes }\end{array}$ & [83] \\
\hline CD55 & $\begin{array}{l}\text { Decay accelerating } \\
\text { factor }\end{array}$ & $\begin{array}{l}\text { MCA44 } \\
\text { Mouse } \\
\text { lgG1 }\end{array}$ & $\begin{array}{l}\text { Blocks complement } \\
\text { regulatory activity on } \\
\text { guinea pig erythrocytes }\end{array}$ & [84] and [85] \\
\hline CD68 & CD68 antigen & $\begin{array}{l}\text { PM-1K } \\
\text { Mouse }\end{array}$ & & [86] \\
\hline CD90 & Thy- 1 antigen & $\begin{array}{l}\mathrm{H} 154 \\
\text { Rat } \\
\text { lgG2a }\end{array}$ & $\begin{array}{l}\text { Co-stimulatory for } \mathrm{T} \\
\text { cell-proliferation, gene } \\
\text { cloned }\end{array}$ & [52] \\
\hline CD90 & Thy-1 antigen & $\begin{array}{l}\text { CT4 } \\
\text { Mouse } \\
\text { lgG3 }\end{array}$ & $\begin{array}{l}\text { Similar to } \mathrm{H} 154 \text {, but } \\
\text { mouse mAb, gene } \\
\text { cloned }\end{array}$ & $\begin{array}{l}{[52],} \\
{[60] \text { and [87] }}\end{array}$ \\
\hline CD90 & Thy-1 antigen & $\begin{array}{l}\text { MSgp2 } \\
\text { Mouse }\end{array}$ & $\begin{array}{l}\text { Similar to } \mathrm{H} 154 \text { and } \\
\text { CT4 but weaker staining }\end{array}$ & [52] and [88] \\
\hline CD90 & Thy-1 antigen & $\begin{array}{l}167 \\
\text { Mouse }\end{array}$ & Similar to MSgp2 & [52] \\
\hline
\end{tabular}


Table 2. Monoclonal antibodies directed against cell surface antigens without cluster of differentiation classification.

\begin{tabular}{|c|c|c|c|c|}
\hline $\begin{array}{l}\text { Antibody- } \\
\text { name }\end{array}$ & Isotype & Specificity & Remarks & Origin/reference \\
\hline H159 & $\begin{array}{l}\text { rat } \\
\lg 2 a\end{array}$ & T cells & Weak staining of $B$ cells & [57] \\
\hline $5 \mathrm{C3}$ & $m s \lg M$ & Activated T cells & Blocks IL2-driven proliferation & [44] and [49] \\
\hline CT5 & $m s \lg G 1$ & $\begin{array}{l}\text { T cells and leukemic } \\
B \text { cells }\end{array}$ & $\begin{array}{l}\text { Considered as pan T cell } \\
\text { marker, but also stains L2C B } \\
\text { cell leukemia }\end{array}$ & [60] \\
\hline MSgp7 & $m s \lg M$ & T cells & $\begin{array}{l}\text { Reacts with T cells and } \\
\text { thymocytes }\end{array}$ & [48] \\
\hline MSgp12 & ms lgG1 & T cells & $\begin{array}{l}\text { Reacts with a subpopulation of } \\
T \text { cells and thymocytes } \\
\text { potential anti-CD4 }\end{array}$ & [48] \\
\hline 31D2 & ms lgG1 & B cells (surface IgM) & $\begin{array}{l}\text { Binds soluble and surface IgM, } \\
\text { does not stimulate B cell } \\
\text { proliferation }\end{array}$ & \\
\hline B621 & $\begin{array}{l}\text { rat lgG1 } \\
\lambda \text { light } \\
\text { chain }\end{array}$ & $\begin{array}{l}\text { B-cells (surface } \\
\text { Immunoglobulin) }\end{array}$ & Similar to 31D2 & \\
\hline 188 & $\begin{array}{l}\text { ms } \\
\lg 22 b\end{array}$ & $\mathrm{~T}$ - and B-cells & $\begin{array}{l}\text { Inhibits T cell proliferation, } \\
\text { stains weakly, good } \\
\text { complement mediated } \\
\text { cytotoxicity }\end{array}$ & [50] \\
\hline $\mathrm{H} 160$ & $\begin{array}{l}\text { rat } \\
\lg G 2 a\end{array}$ & Leukocytes & $\begin{array}{l}\text { Strongly inhibits } \mathrm{T} \text { cell } \\
\text { proliferation }\end{array}$ & \\
\hline 342 & $m s \lg M$ & Macrophages & $\begin{array}{l}\text { Broad range of macrophages } \\
\text { Good induction of complement- } \\
\text { mediated cytotoxicity }\end{array}$ & [63] \\
\hline 305 & $\begin{array}{l}\mathrm{ms} \\
\lg \mathrm{g} 2 \mathrm{a}\end{array}$ & Macrophages & Stains most macrophages & [63] \\
\hline 249 & $m s \lg G 1$ & $\begin{array}{l}\text { Macrophages and } \\
\text { platelets }\end{array}$ & & [63] \\
\hline MR-1 & $m s \lg G 1$ & $\begin{array}{l}\text { Macrophages and } \\
\text { monocytes }\end{array}$ & Intracellular antigen & [64] \\
\hline VIIA1 & $m s \lg G 1$ & Macrophages & binds Fc Receptor 2 & [89] \\
\hline VIA2 & ms lgG1 & Macrophages & Binds Fc Receptor 1 and 2 & {$[89]$} \\
\hline
\end{tabular}


Table 3. MHC-specific monoclonal antibodies.

\begin{tabular}{|c|c|c|c|c|}
\hline $\begin{array}{l}\text { Antibody- } \\
\text { name }\end{array}$ & Isotype & Specificity & Remarks & Origin/reference \\
\hline MSgp4 & $\begin{array}{l}\mathrm{ms} \\
\mathrm{lgG} 1\end{array}$ & $\begin{array}{l}\text { MHC class } \\
\text { I }\end{array}$ & $\begin{array}{l}\text { Stains all immune cells except cortical } \\
\text { thymocytes, immunoprecipitated a } 45 \mathrm{kD} \\
\text { antigen and beta-2-microglobulin }\end{array}$ & [48] and [47] \\
\hline B640 & $\begin{array}{l}\mathrm{ms} \\
\mathrm{lgG} 1\end{array}$ & $\begin{array}{l}\text { MHC class } \\
\text { I }\end{array}$ & $\begin{array}{l}\text { Similar to MSgp4, specificity confirmed by } \\
\text { binding to recombinant class I gene on } \\
\text { transfected cells }\end{array}$ & \\
\hline $\begin{array}{l}\text { HUSM-20 } \\
\text { HUSM-41 }\end{array}$ & $\begin{array}{l}\mathrm{ms} \\
\lg \mathrm{g} 2 \mathrm{a}\end{array}$ & MHC class & $\begin{array}{l}\text { Specificity appraised from } \\
\text { immunohistological staining }\end{array}$ & [53] \\
\hline MSgp8 & $\begin{array}{l}\text { Ms } \\
\lg \text { G3 }\end{array}$ & $\begin{array}{l}\text { MHC class } \\
\text { II }\end{array}$ & Good for tissue staining & {$[48]$} \\
\hline 25E3 & $\begin{array}{l}\text { ms } \\
\lg G 1\end{array}$ & $\begin{array}{l}\text { MHC class } \\
\text { II }\end{array}$ & $\begin{array}{l}\text { Inhibits T cell-proliferation } \\
\text { Strain } 2 \text { specific }\end{array}$ & [41], \\
\hline 22C4 & $\begin{array}{l}\text { ms } \\
\text { lgG1 }\end{array}$ & $\begin{array}{l}\text { MHC class } \\
\text { II }\end{array}$ & $\begin{array}{l}\text { Inhibits T cell-proliferation } \\
\text { Reacts with cells of strain } 2 \text { and strain } 13 \\
\text { animals }\end{array}$ & $\begin{array}{l}{[41],} \\
{[42] \text { and [58] }}\end{array}$ \\
\hline $\mathrm{Cl}-13.1$ & & $\begin{array}{l}\text { MHC class } \\
\text { II }\end{array}$ & $\begin{array}{l}\text { Specific for strain } 13 \text { and outbred gpips, } \\
\text { negative on strain } 2 \text { cells }\end{array}$ & [60] \\
\hline $\begin{array}{l}\text { HUSM-19 } \\
\text { HUSM-45 } \\
\text { HUSM-49 }\end{array}$ & $\begin{array}{l}\mathrm{ms} \\
\lg \mathrm{g} 2 \mathrm{a}\end{array}$ & $\begin{array}{l}\text { MHC class } \\
\text { II }\end{array}$ & $\begin{array}{l}\text { Specificity appraised from } \\
\text { immunohistological staining }\end{array}$ & [53] \\
\hline
\end{tabular}

Table 4. Guinea pig tumor cell lines.

\begin{tabular}{|c|c|c|c|c|c|}
\hline Designation & Morphology & Source/organ & Growth & $\begin{array}{c}\text { ATCC- } \\
\text { number }\end{array}$ & Ref. \\
\hline $104 \mathrm{C} 1$ & Fibroblast & LUNG & Adherent & CRL-1405 & [55] \\
\hline JH4 clone 1 & Fibroblast/epithelial & FETUS & Adherent & CCL-158 & {$[90]$} \\
\hline GPC 16 & Epithelial & Colon & Adherent & CCL-242 & [91] \\
\hline $\mathrm{EN} \mathrm{L}_{2} \mathrm{C}$ & Lymphoid & Blood & $\begin{array}{l}\text { In } \\
\text { vivo/leukemia }\end{array}$ & n.a. & [92] and [93] \\
\hline $\mathrm{BZ} \mathrm{L}_{2} \mathrm{C}$ & Lymphoid & Blood & $\begin{array}{l}\text { In } \\
\text { vivo/leukemia }\end{array}$ & n.a. & [94] \\
\hline Line-10 & Variable & Liver & In vivo/ascites & n.a. & [95] \\
\hline
\end{tabular}

